\title{
Specific Deficiency in Nuclear Factor- $\kappa$ B Activation in Neurons of the Central Nervous System
}

\author{
Keith W. Jarosinski, Laurie W. Whitney, and Paul T. Massa \\ Departments of Neurology (LWW, PTM) and Microbiology and Immunology (KWJ, PTM), State University of New \\ York Health Science Center, Syracuse; and Department of Microbiology and Immunology (KWJ), Veterinary Medical \\ Center, College of Veterinary Medicine, Cornell University, Ithaca, New York
}

\begin{abstract}
SUMMARY: The expression and activation of nuclear factor $-\kappa \mathrm{B}(\mathrm{NF}-\kappa \mathrm{B})$ in neurons and glia of the central nervous system (CNS) has been intensely investigated because of its potential importance in understanding how this multifunctional transcription factor controls developmental and pathological processes. In particular, there has been interest in how NF- $\kappa \mathrm{B}$ may be differentially regulated in these two major functional subgroups of cells in the CNS to provide for specific responses to various stimuli. Of special interest are responses to both proinflammatory cytokines and microbial products that signal from specific cell receptors to activate NF- $\kappa \mathrm{B}$. In the present studies, both neurons and glia (astrocytes) in vivo expressed latent cytoplasmic NF- $\kappa \mathrm{B}$ analyzed by immunofluorescence microscopy and electrophoretic mobility shift analysis. In vitro, neurons and astrocytes expressed comparable levels of latent NF- $\kappa \mathrm{B}$ molecules, but NF- $\kappa \mathrm{B}$ nuclear localization stimulated by proinflammatory cytokines or microbial products was markedly deficient in neurons. In accord with this finding, the rapid degradation of inhibitor of NF- $\kappa \mathrm{B}$ alpha $\left(I_{\kappa} \mathrm{B} \alpha\right)$ that is seen in astrocytes did not occur in neurons in response to these agents. However, long-term exposure to translational inhibitors resulted in $\mathrm{I} \kappa \mathrm{B} \alpha$ decay and activation of latent $\mathrm{NF}-\kappa \mathrm{B}$ in neurons, indicating potential NF- $\kappa \mathrm{B}$ activity in these cells. Analysis of NF- $\kappa$ B-responsive interferon regulatory factor- 1 gene expression indicated that increased nuclear NF- $\kappa \mathrm{B}$ in neurons had transcriptional potential. We conclude that mechanisms responsible for inducible targeting of $I_{\kappa} \mathrm{B} \alpha$ are uniquely regulated in neurons and account for the hypo-responsiveness of these cells to signals generated during microbial infections in the CNS. Thus, modulation of signals that target $I \kappa \mathrm{B} \alpha$ degradation may be unique and a key component of specific NF- $\kappa \mathrm{B}$ regulation in neurons. (Lab Invest 2001, 81:1275-1288).
\end{abstract}

$R$ egulation of the nuclear factor- $\kappa \mathrm{B}(\mathrm{NF}-\kappa \mathrm{B})$ pathway in the central nervous system (CNS) has become a topic of recent interest because of implications for the development and pathology of the CNS (Mattson et al, 2001; Grilli and Memo, 1999b; O'Neill and Kaltschmidt, 1997). The NF- $\kappa$ B pathway is a key component of the cellular response to external stimuli, such as tumor necrosis factor- $\alpha$ (TNF- $\alpha$ ), interleukin-1 $\beta$ (IL$1 \beta$ ), ultraviolet light, lipopolysaccharide (LPS), and viral signaling molecules (eg, double-stranded RNA [dsRNA] or Epstein-Barr virus latent membrane protein 1 [EBVLMP1]) (Devergne et al, 1998; Didonato et al, 1996; Donald et al, 1995; Grilli et al, 1993; Sen and Baltimore, 1986; Zamanian-Daryoush et al, 2000). NF- $\kappa \mathrm{B}$ is known to mediate induction of many genes containing consensus $\kappa \mathrm{B}$ elements within their gene promoters (Baeuerle, 1991). Generally, NF- $\kappa$ B-responsive genes encode both intracellular and cell surface molecules that are increased during both innate and adaptive immune responses to pathogens. Some representative genes increased in these responses include TNF- $\alpha$ (Drouet et al, 1991), IL-6 (Liberman and Baltimore, 1990), major histo-

Received June 6, 2001.

This work was supported by a grant from the National Multiple Sclerosis Society.

Address reprint requests to: Dr. Paul T. Massa, Department of Neurology, SUNY Health Science Center, UH5816, 750 East Adams St., Syracuse, New York, 13210. E-mail: massap@mail.upstate.edu compatibility complex (MHC) genes (Ten et al, 1993), intracellular adhesion molecule-1 (ICAM-1) (Ohmori et al, 1997), inducible nitric oxide synthase (iNOS) (Xie et al, 1993), Bcl family molecules (Chen et al, 2001; Glasgow et al, 2001), Fas/FasL (Harwood et al, 2001; Kuhnel et al, 2001; Lee et al, 2001), p53 (Grimm et al, 1996), and interferon regulatory factor 1 (IRF-1) (Imanishi et al, 2000; Ohmori et al, 1997).

$\mathrm{NF}-\kappa \mathrm{B}$ was originally identified as a heterodimer of two molecules, p50 and p65 (RelA), and was shown to be constitutively present in the cytoplasm of cells in an inactive latent form (Lenardo and Baltimore, 1989; Sen and Baltimore, 1986). The NF- $\kappa \mathrm{B}$ inhibitor, inhibitor of $\mathrm{NF}-\kappa \mathrm{B}$ alpha $\left(\mathrm{I}_{\kappa} \mathrm{B} \alpha\right)$, sequesters NF- $\kappa \mathrm{B}$ molecules in the cytoplasm and restricts access of NF- $\kappa$ B to the nucleus (Arenzana-Seisdedos et al, 1997; Baldwin, 1996). NF- $\kappa$ B inducers such as TNF- $\alpha$, LPS, or dsRNA generate intracellular signals that lead to phosphorylation on serines 32 and 36 of $\mathrm{I}_{\kappa} \mathrm{B} \alpha$ by $\mathrm{I}_{\kappa} \mathrm{B} \alpha$ kinases (IKK-1/2) (Traenckner et al, 1995; Woronicz et al, 1997; Zamanian-Daryoush et al, 2000; Zandi et al, 1997), followed by ubiquitination and degradation of $\mathrm{I}_{\kappa} \mathrm{B} \alpha$ by the $26 S$ proteasome (Palombella et al, 1994). The $\mathrm{NF}-\kappa \mathrm{B}$ dimers are then freed from $\mathrm{I} \kappa \mathrm{B} \alpha$, allowing them to translocate into the nucleus via a nuclear localization signal (Finco and Baldwin, 1995).

$\mathrm{NF}-\kappa \mathrm{B}$ activation may be induced by a variety of signals mediated by specific cell surface receptors when bound by extracellular ligands such as cytokines 
and microbial products. In response to various ligands, CNS neurons and glia have been found to express inducible nuclear NF- $\kappa \mathrm{B}$. Studies on the role of $\mathrm{NF}-\kappa \mathrm{B}$ in neurons have centered primarily on the regulation of apoptosis (Grilli and Memo, 1999b; Mattson et al, 2001). Indeed, prior studies showed that $\mathrm{NF}-\kappa \mathrm{B}$ increased transcription of antiapoptotic genes in multiple tissues and cell lines and thus may serve a general role in cell survival mechanisms (Beg and Baltimore, 1996; Liu et al, 1996; Song et al, 1996; Wang et al, 1998). In contrast, investigations of NF- $\kappa \mathrm{B}$ function in astrocytes has focused on its role in increased expression of proinflammatory cytokines, chemokines, and immunological cell surface molecules that promote immune responses (Lieb et al, 1996; Massa and Wu, 1998; Nazar et al, 1997; Sparacio et al, 1992). It is currently unknown whether there is a dichotomy of NF- $\kappa \mathrm{B}$ function in neurons and glia or whether signals that promote these functions through $\mathrm{NF}-\kappa \mathrm{B}$ activity are distinct.

The role of $\mathrm{NF}-\kappa \mathrm{B}$ in either promoting or inhibiting apoptosis in cells including neurons has been extensively described, but the conditions required for these opposite effects are currently unclear and controversial (Barkett and Gilmore, 1999; Bournat et al, 2001; Cheema et al, 1999; Grilli and Memo, 1999a, 1999b; Grimm et al, 1996; Kaltschmidt et al, 2001; Mattson et al, 1997, 2001; O'Neill and Kaltschmidt, 1997; Schneider et al, 1999; Tamatani et al, 1999, 2001; Won et al, 1999). During embryonic CNS development, NF- $\kappa \mathrm{B}$ is likely to be extremely important, as in other tissues, for neuroblast survival ( $\mathrm{Li}$ et al, 2001a). However, the exact status of NF- $\kappa \mathrm{B}$ activation in mature neurons of the adult CNS is questionable. Initial studies of the expression of NF- $\kappa \mathrm{B}$ in the CNS noted the conspicuous lack of nuclear binding activity compared with many other tissues (Burke et al, 1989). These studies were followed by many in vitro studies showing the lack of nuclear NF- $\kappa$ B binding activity in neurons, both in primary cultures and in neuronal cell lines (DhibJalbut et al, 1999; Drew et al, 1993; Massa et al, 1993; Ward and Massa, 1995). Since these initial observations, reports on ubiquitous constitutive nuclear $\mathrm{NF}-\kappa \mathrm{B}$ activity in CNS neurons indicated a unique constitutive role in these cells (Kaltschmidt et al, 1994). Nonetheless, other studies by these authors found that NF- $\kappa \mathrm{B}$ may be primarily in the latent inducible form in the CNS (Kaltschmidt et al, 1993). Therefore, it is currently uncertain whether NF- $\kappa \mathrm{B}$ is primarily latent or active in CNS neurons and which signals may be important for activation. This is a particularly important consideration in immunological responses of the CNS because deficient activation of NF- $\kappa \mathrm{B}$ in neurons is thought to be an important mechanism of the transcriptional silence of MHC class I genes and neuronal immunoprivilege (Dhib-Jalbut et al, 1999; Drew et al, 1993; Massa et al, 1999). Taken together, these studies indicate that the activation of NF- $\kappa \mathrm{B}$ may be a highly regulated process in neurons compared with other cell types.

The present studies are focused on clarifying the potential responsiveness of neurons and astrocytes to proinflammatory cytokines and microbial products that may be important for regulating NF- $\kappa \mathrm{B}$-inducible genes in the CNS. We demonstrate here that neurons specifically lack significant inducible NF- $\kappa \mathrm{B}$ binding activity and $\mathrm{NF}-\kappa \mathrm{B}$ responsive gene IRF-1 relative to astrocytes following stimulation with multiple agents. Moreover, multiple agents that induce rapid $I_{\kappa} \mathrm{B} \alpha$ degradation in astrocytes fail to induce $\mathrm{I}_{\kappa} \mathrm{B} \alpha$ degradation in neurons. Finally, by blocking protein synthesis in neurons over long periods of time, decay of $I_{\kappa} \mathrm{B} \alpha$ resulted in increased NF- $\kappa \mathrm{B}$ binding activity, indicating the potential for $\mathrm{NF}-\kappa \mathrm{B}$ transcriptional activity in neurons under some conditions. We propose that these observations reveal a fundamental difference in the pathways that regulate NF- $\kappa \mathrm{B}$ activation in neurons and glia in the CNS and that this difference may relate to the specific functional requirements of these cells.

\section{Results}

\section{Tissue-Specific Lack of NF-кB Binding Activity in the CNS}

Using electrophoretic mobility shift assays (EMSA), we first determined whether constitutive NF- $\kappa$ B activity may be either lacking or present in the CNS as previously described by others (Burke et al, 1989; Kaltschmidt et al, 1994). Nuclear extracts from either the brain, skin, or spleen were analyzed using the IRF-1- $\kappa$ B site (Fig. 1) or with a retinoic acid responsive element (RARE) as an unrelated probe. Abundant $\mathrm{NF}-\kappa \mathrm{B}$ binding activity could be found in both skin and spleen in agreement with previous studies on its constitutive activity in these tissues $(\mathrm{Hu}$ et al, 1999; Karin and Delhase, 2000; Lenardo and Baltimore, 1989). However, brain entirely lacked active NF- $\kappa B$ binding activity (Fig. 1A). This lack was specific for $\mathrm{NF}-\kappa \mathrm{B}$ because abundant RARE binding activity in the same brain extracts was detected (Fig. 1B). To determine whether NF- $\kappa \mathrm{B}$ was expressed in the CNS in the cytoplasm or nucleus, tissue sections were stained with the p65 (RelA) component of NF- $\kappa$ B. Sections were also doubly labeled for either neuron-specific neurofilament protein or astrocyte-specific glial fibrillary acidic protein (GFAP) to identify neurons and astrocytes. Figure 1, C and D, showed that large neurofilament-positive neurons in the cerebral cortex expressed cytoplasmic but no detectable nuclear RelA. Also, GFAP-positive astrocytes throughout the CNS, including brain stem and cerebral cortex, expressed distinct cytoplasmic RelA, but their nuclei did not appear stained (Fig. 1, E and F, arrowheads). Indeed, no CNS cells in any brain region expressed detectable RelA in the nucleus, which is in agreement with the entire lack of NF- $\kappa$ B binding activity in EMSA (Fig. 1A). Therefore, NF- $\kappa \mathrm{B}$ in the brain does not appear to be substantially activated in either neurons or glia and primarily resides in the cytoplasm, most likely in a latent state. 

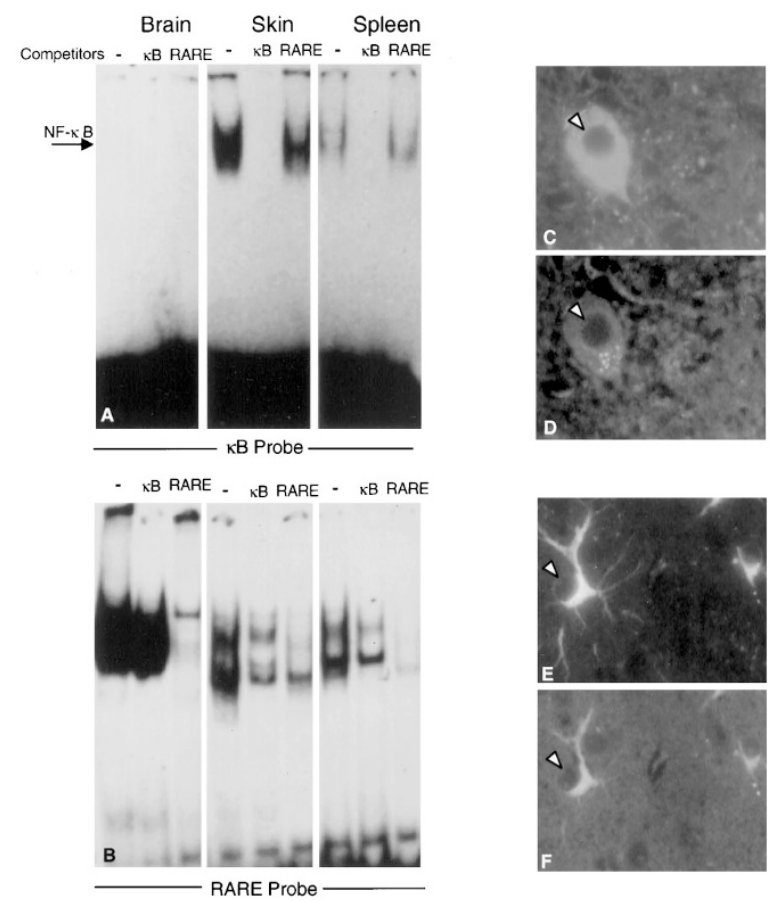

Figure 1.

Nuclear factor $\kappa \mathrm{B}(\mathrm{NF}-\kappa \mathrm{B})$ localization and binding activity in the brain. $\mathrm{A}$, Electrophoretic mobility shift assay (EMSA) of nuclear extracts prepared from fresh mouse brain, skin, and spleen. The synthetic oligonucleotide with a $\kappa B$ sequence identical to the interferon regulatory factor-1 (IRF-1)- $\kappa$ B site was used as a probe for NF- $\kappa$ B. B, EMSA using a retinoic acid-responsive element (RARE). C and D, Double immunofluorescence of neurofilament protein (C) and cytoplasmic NF- $\kappa B$ RelA (D) in the adult mouse cerebral cortex. $E$ and $F$, Double immunofluorescence of glial fibrillary acidic protein $(\mathrm{E})$ and cytoplasmic NF- $\kappa$ B RelA (F) of astrocytes in the mouse cerebral cortex. In C to F, nuclei of neurons and astrocytes are indicated (arrowheads).

\section{Absence of Nuclear p65 (RelA) Translocation in Neurons Cultured from Cerebral Cortex}

To determine conditions that may be responsible for activation of NF- $\kappa \mathrm{B}$ in neurons and glia, we prepared neuron and astrocyte cultures that would allow treatment with various NF- $\kappa$ B inducers. For immunohistochemical analysis, mixed cultures of astrocytes and neurons were cultivated from the cerebral cortex of 8-day-old mice and treated with either TNF- $\alpha$, LPS, or cycloheximide. The cells were then fixed and stained for RelA to examine expression and nuclear localization of NF- $\kappa \mathrm{B}$. To ascertain the identity of neurons or astrocytes, the cells were double-stained for either neuron-specific neurofilament protein or GFAP subsequent to the RelA staining. Neurofilament-positive cerebral neurons, either in untreated cultures or in cultures exposed to TNF- $\alpha$, LPS, or cycloheximide, did not express any detectable NF- $\kappa$ B RelA (Fig. 2). Rather, RelA remained conspicuously localized in the neuronal cytoplasm in a perinuclear pattern. In contrast, GFAP-positive astrocytes in these cultures were highly responsive to either TNF- $\alpha$, LPS, or cycloheximide, showing increased nuclear translocation of RelA compared with untreated cultures (Fig. 3). These data indicated a profound difference in responsiveness of neurofilament-positive neurons and GFAP-positive astrocytes to either cytokines, microbial products, or cycloheximide with respect to nuclear translocation of $\mathrm{NF}-\kappa \mathrm{B}$.

\section{General Deficiency in NF-кB Binding Activity in Response to Multiple Inducers in Neurons}

The proximal $\kappa \mathrm{B}$ site of the IRF-1 promoter (Harada et al, 1994; Imanishi et al, 2000; Massa and Wu, 1995; Ohmori et al, 1997) was used in EMSA to analyze $\mathrm{NF}-\kappa \mathrm{B}$ binding in neurons relative to that in astrocytes following treatment with various NF- $\kappa$ B inducers. Cerebellar granule cell neuron cultures were chosen to produce nuclear extracts for these studies because of the relatively high purity of these preparations (Meier and Schousboe, 1982). Pure astrocyte cultures were prepared from neonatal cerebral cortex as described (see "Materials and Methods"). In astrocytes treated with LPS, IL- $1 \beta$, or TNF- $\alpha$, NF- $\kappa$ B binding by EMSA was sharply increased (Fig. 4A). In neurons, however, there was considerably lower NF- $\kappa \mathrm{B}$ binding after treatment with these NF- $\kappa$ B inducers (Fig. $4 \mathrm{~B}$ ), which is consistent with the immunohistochemical observations of cerebral neurons. TNF- $\alpha$ at 30 minutes and TNF- $\alpha$ and LPS at 4 hours showed only faint induction of NF- $\kappa \mathrm{B}$ binding in neurons relative to astrocytes. The lack of NF- $\kappa$ B induction in neurons did not relate to a lack of NF- $\kappa B$ subunit expression because Western immunoblots of p50 and RelA showed approximately equal levels of these subunits in neurons and astrocytes (Fig. 4C). Interestingly, induction of NF- $\kappa \mathrm{B}$ containing both p50 and RelA subunits in neurons was comparable with astrocytes following longer-term cycloheximide treatment (6 hours), which is known to decrease synthesis and steady state levels of $1 \kappa \mathrm{B} \alpha$ (Fig. 4B). In contrast, longer-term treatment with either TNF- $\alpha$ or LPS did not lead to increased NF- $\kappa$ B activation in neurons (data not shown). Taken together, these observations indicate that the lack of $N F-\kappa B$ activation in neurons in response to cytokines or microbial agents most likely relates to deficiencies in signaling pathways responsible for NF- $\kappa \mathrm{B}$ activation.

\section{Multiple Protein Synthesis Inhibitors Increase NF-кB in Neurons}

Of the various NF- $\kappa \mathrm{B}$ inducers tested, the protein synthesis inhibitor cycloheximide effectively increased $\mathrm{NF}-\kappa \mathrm{B}$ binding activity in neurons when treated over long periods ( 6 hours vs 0.5 hours; Fig. $4 \mathrm{~A}$ ). The most likely mechanism for protein synthesis inhibitor activity is through reduction of de novo synthesis of $I_{\kappa} \mathrm{B} \alpha$, which decays under these conditions and allows $\mathrm{NF}-\kappa \mathrm{B}$ translocation to the nucleus (Newton et al, 1996). However, cycloheximide may also signal in cells by ribotoxic stress-activated signaling pathways (Cano et al, 1994; Faggioli et al, 1997; Hazzalin et al, 1997, 1998), involving molecules common to NF- $\kappa \mathrm{B}$ activation (Lee et al, 1997; Li et al, 2001b; Liu et al, 1996). To determine whether the induction of NF- $\kappa \mathrm{B}$ was generally related to inhibition of protein synthesis in neurons, other unrelated inhibitors that act by distinct mechanisms on ribosome activity and do not 

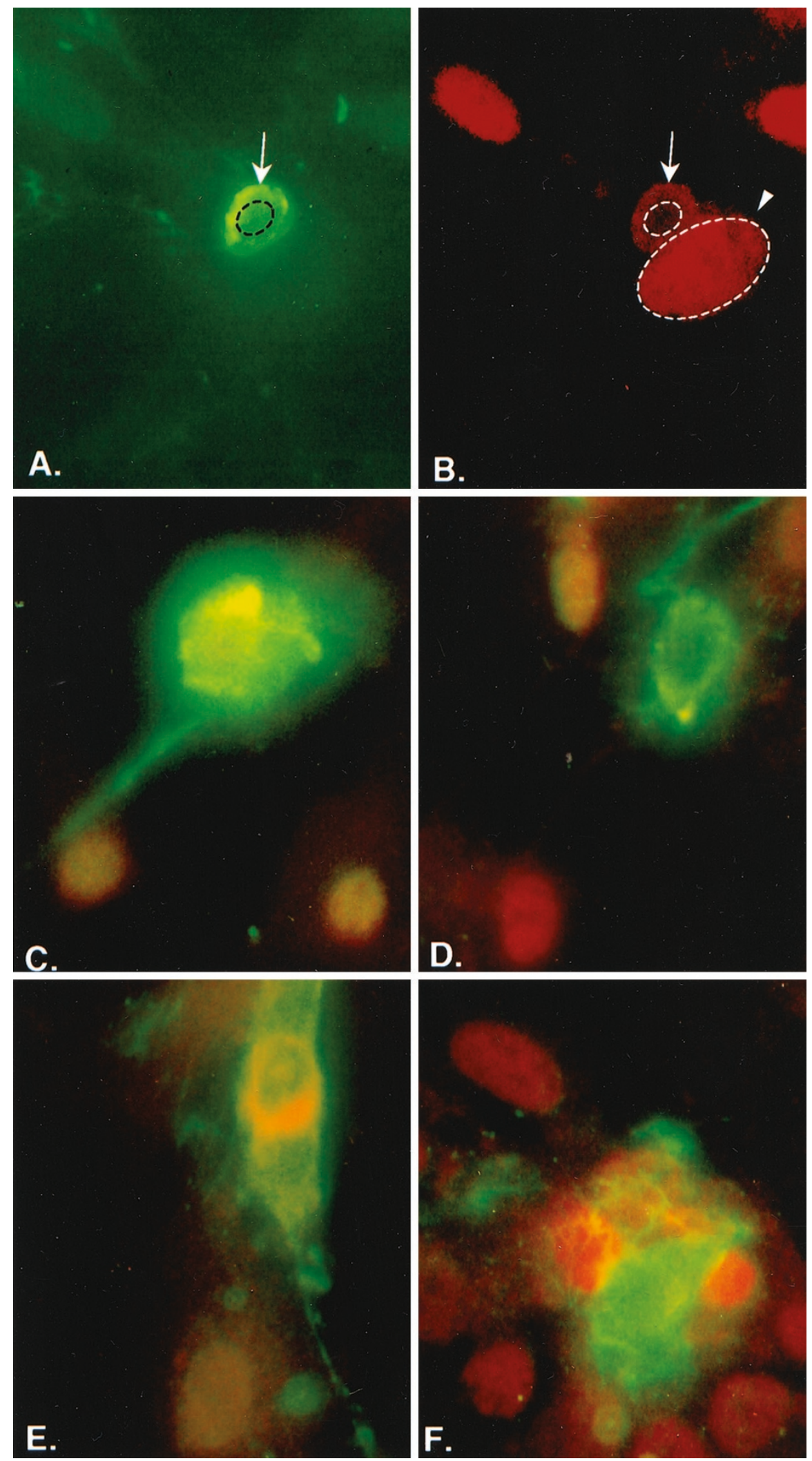

Figure 2.

$A$ and B, Double immunofluorescence of neuron/glia cultures treated with lipopolysaccharide (LPS) and stained for both neurofilament (A) and NF- $\kappa$ B RelA (B). Arrow. Neurofilament positive neuron (A, green) with cytoplasmic RelA (B, red). Arrowhead points to neurofilament-negative astrocyte nuclei with characteristic oval profile visibly stained for RelA in B (see Fig. 3). Representative nuclear profiles are demarcated with dashed lines. C to F, In situ double exposure immunofluorescence of the RelA component of NF- $\kappa$ B and neuron-specific neurofilament proteins in neurons cultured from the mouse cerebral cortex treated with either control medium (C), cycloheximide (D), tumor necrosis factor- $\alpha$ (TNF- $\alpha)$ (E), or LPS (F). 



Figure 3.

Nuclear translocation of NF- $\kappa$ B RelA in response to LPS. Astrocytes were treated for 1 hour with either control medium (Co) or with LPS and then double-stained for both glial fibrillary acidic protein (GFAP) and the RelA subunit of NF- $\kappa$ B. In the lower panels (LPS), arrowheads mark individual astrocytes stained for GFAP, in which RelA has been redistributed from the cytoplasm to the nucleus compared with upper panels.

induce ribotoxic stress signaling (puromycin and emetine) (Cano et al, 1994) were tested. In astrocytes, all protein synthesis inhibitors tested induced NF- $\kappa$ B to levels seen in response to a 4-hour exposure to TNF- $\alpha$, LPS, and viral mimic poly dl:dC. Interferon- $\gamma$ $($ IFN- $\gamma$ ) was ineffective in inducing $N F-\kappa B$ over this time period (vida infra). In neurons, the other protein synthesis inhibitors also increased NF- $\kappa$ B to levels seen with cycloheximide (Fig. 5), indicating that all inhibitors most likely acted through inhibition of protein synthesis rather than by alternate ribotoxic pathways. The latter was supported by the low responsiveness of neurons to anisomycin used at concentrations below that required for blocking protein synthesis but sufficient to cause ribotoxic stress (Fig. 4B) (Cano et al, 1994). Interestingly, this low concentration of anisomycin was able to induce much higher levels of $\mathrm{NF}-\kappa \mathrm{B}$ in astrocytes compared with neurons, indicating that ribotoxic stress may play a role in $N F-\kappa B$ activation in astrocytes (Fig. $5 \mathrm{~A}$ ) but not in neurons (Fig. 5B). Therefore, these data indicate that protein synthesis inhibition of $\mathrm{I}_{\kappa} \mathrm{B} \alpha$, rather than rapid induction of NF- $\kappa$ B activation, is the mechanism of action of protein synthesis inhibitors in nuclear translocation of $\mathrm{NF}-\kappa \mathrm{B}$ in neurons.

\section{Neurons Lack Cytokine-Inducible lкBa Degradation}

$I_{\kappa} \mathrm{B} \alpha$ degradation is a prerequisite for $\mathrm{NF}-\kappa \mathrm{B}$ activation in response to cytokines, LPS, or dsRNA. Therefore, we determined whether the lack of NF- $\kappa$ B activation in neurons in response to these agents was due to a lack of rapid $I_{\kappa} \mathrm{B} \alpha$ degradation. Initially, we chose to analyze the kinetics of $I \kappa \mathrm{B} \alpha$ degradation in neurons and astrocytes in response to a well-characterized NF- $\kappa \mathrm{B}$ inducer, TNF- $\alpha$, which has previously been shown to initiate a rapid degradation and subsequent positive autoregulation of $\mathrm{I}_{\kappa} \mathrm{B} \alpha$ (Sun et al, 1993). Analysis of $I_{\kappa} \mathrm{B} \alpha$ degradation induced by TNF- $\alpha$ showed that, 15 minutes after treatment, astrocytes had little $I_{\kappa} \mathrm{B} \alpha$ remaining compared with untreated cells, but that by 30 minutes, $I_{\kappa} \mathrm{B} \alpha$ levels began to increase by autoregulation (Fig. 6A). In sharp contrast, neurons showed little decrease in $I_{\kappa} \mathrm{B} \alpha$ levels following treatment with TNF- $\alpha$ for up to 120 minutes after treatment, and no positive autoregulation was apparent (Fig. 6A). These data indicate a neuron-specific lack in signaling to $\mathrm{I}_{\kappa} \mathrm{B} \alpha$ degradation in response to TNF- $\alpha$.

To determine whether lack of $I_{\kappa} \mathrm{B} \alpha$ degradation was a generalized response of neurons or rather specifically related to a lack of $\mathrm{TNF}-\alpha$ responsiveness, we 


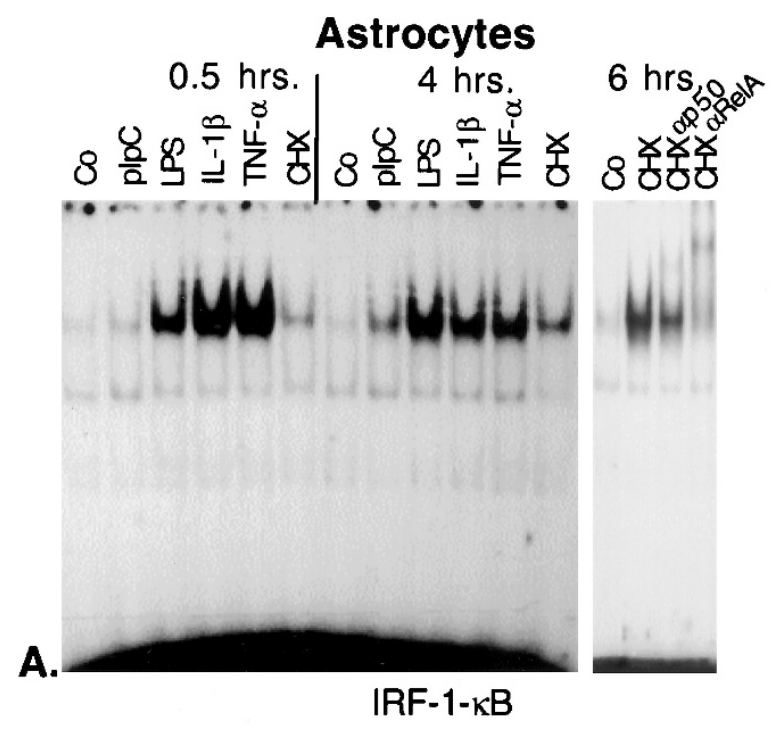

Neurons



IRF-1-kB

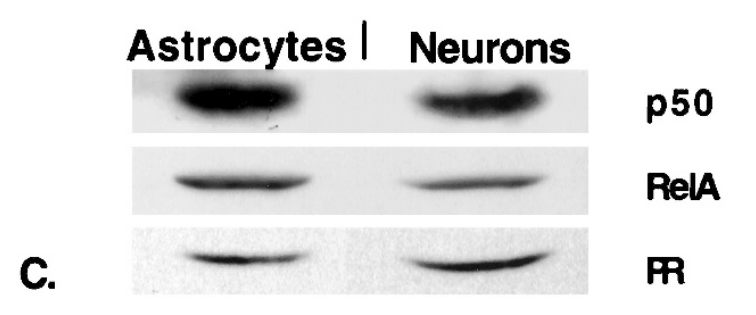

Figure 4.

Astrocytes $(A)$ and neurons $(B)$ were treated with medium alone $\left(\mathrm{C}_{0}\right)$, dsRNA (plpC), LPS, interleukin-1 $\beta$ (IL-1 $\beta$ ), TNF- $\alpha$, and cycloheximide (CHX) for 0.5 and 4 hours, and also for 6 hours with $\mathrm{CHX}$. Nuclear extracts were used for EMSA analysis using the ${ }^{32} \mathrm{P}$-labeled duplex oligonucleotide IRF-1- $\kappa \mathrm{B}$ probe. C, Western immunoblot for p50 (NF $\kappa$ B1) and p65 (Rel A) of astrocytes and neurons. PR, total relative protein levels.

performed an experiment similar to that described above in Figure 6A. Using multiple inducers, the cells were treated with cycloheximide to block de novo $\mathrm{I}_{\kappa \mathrm{B}} \alpha$ autoregulation (Natoli et al, 1997; Newton et al, 1996; Sun et al, 1993), therefore allowing better as-

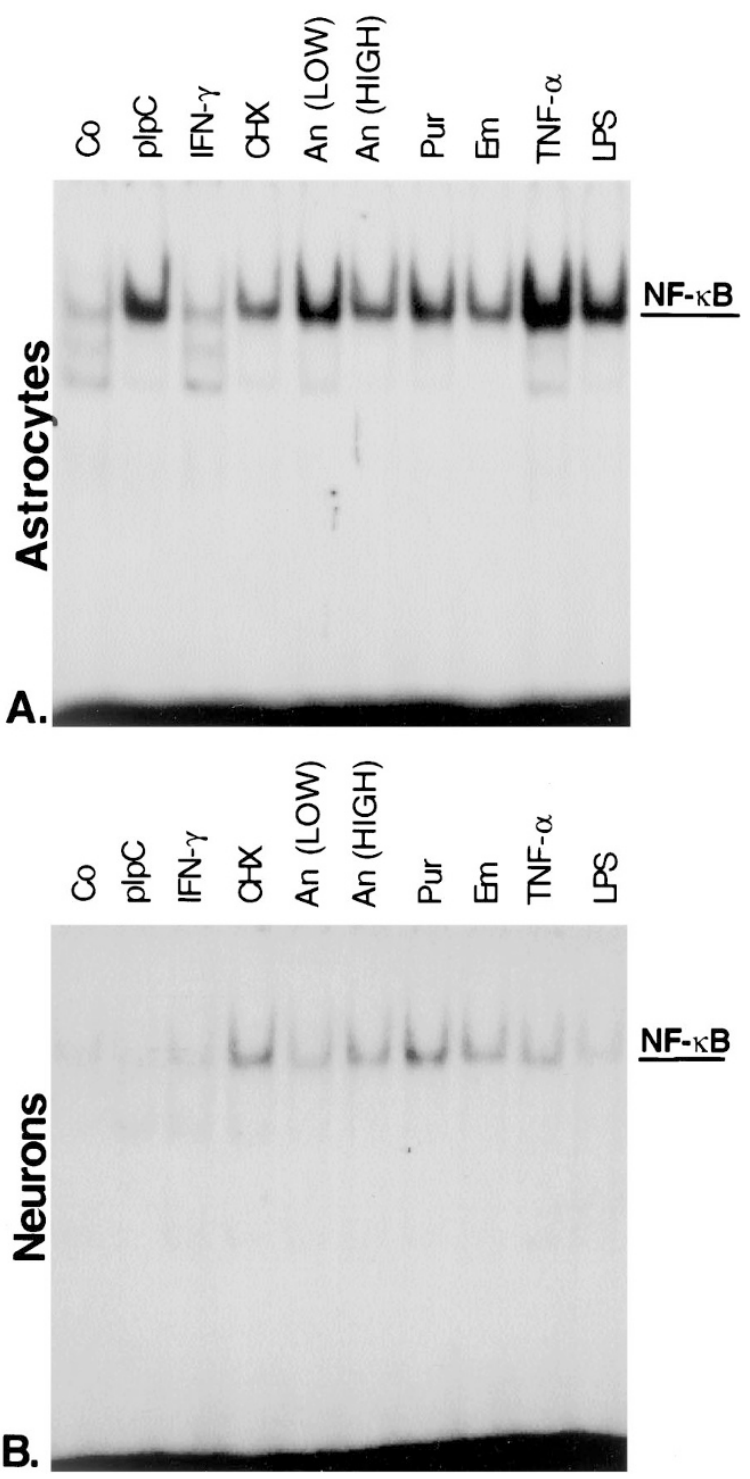

Figure 5.

Astrocyte $(A)$ and neuron (B) cultures were treated with medium alone $(\mathrm{C} 0)$, plpC, interferon-g (IFN- $\gamma$ ), CHX, $250 \mathrm{ng} / \mathrm{ml}$ anisomycin (An LOW), $10 \mu \mathrm{g} / \mathrm{ml}$ anisomycin (An HIGH), puromycin (Pur), emetine (Em), TNF- $\alpha$, or LPS for 4 hours, and nuclear extracts were prepared. Nuclear extracts were used for EMSA analysis using the ${ }^{32} \mathrm{P}$-labeled duplex oligonucleotide IRF-1-кB probe.

sessment of targeted degradation. Western blot analysis of $I_{\kappa} \mathrm{B} \alpha$ showed that a 1-hour treatment with IL-1 $\beta$ or TNF- $\alpha$ led to dramatically decreased levels of $I_{\kappa} \mathrm{B} \alpha$ in astrocytes with less than $5 \%$ of $\mathrm{I}_{\kappa} \mathrm{B} \alpha$ of untreated cultures or approximately $10 \%$ of cultures treated with cycloheximide alone (Fig. 6B). Under the same conditions, neurons completely lacked cytokine-induced degradation of the $\mathrm{I}_{\kappa} \mathrm{B} \alpha$ molecule in response to either TNF- $\alpha$, IL- $1 \beta$, or the other inducers, indicating that the lack of NF- $\kappa \mathrm{B}$ activation in neurons directly correlated with a generalized deficiency in inducible $I_{\kappa} \mathrm{B} \alpha$ degradation.

Next, we determined whether the protein synthesis inhibitors would lead to a long-term decay of $\mathrm{I}_{\kappa} \mathrm{B} \alpha$ in neurons. All of the inhibitors reduced $I_{\kappa} \mathrm{B} \alpha$ levels when used at inhibitory concentrations for prolonged peri- 



Figure 6.

$I_{\kappa} \mathrm{B} \alpha$ degradation in astrocytes, but not in neurons, following stimulation with multiple agents. A, Western blot analysis of astrocyte and neuron cellular protein for $I_{\kappa} B \alpha$ levels. Astrocytes and neurons were treated with either medium alone (Co) or $1000 \mathrm{U} / \mathrm{ml} \mathrm{TNF}-\alpha$ for $15,30,60$, or 120 minutes, and whole cell extracts were analyzed for $I_{\kappa} \mathrm{B} \alpha$ levels. B, Astrocytes and neurons were pretreated with $\mathrm{CHX}$ for 0.5 hours, then additionally treated for 1 hour with either medium alone (Co), plpC, LPS, IL-1 $\beta$, TNF- $\alpha$, IFN- $\gamma, 250 \mathrm{ng} / \mathrm{ml}$ anisomycin (An LOW), or $10 \mu \mathrm{g} / \mathrm{ml}$ An (An HIGH). Percentage (\%) of Co is the percentage of $I_{\kappa} B \alpha$ remaining after treatment with inducers compared with treatment with medium alone (Co). C, Western blot analysis of $I_{\kappa} B \alpha$ levels in astrocyte and neuron cultures treated with medium alone (Co), CHX, An LOW, An HIGH, puromycin (Puro), or emetine (Em) for a prolonged period of time (4 hours). Percentage of $I_{\kappa} B \alpha$ remaining relative to control was determined as in $B$.

ods of time (Fig. $6 \mathrm{C}$ ). Anisomycin had the greatest effect on decreasing $I_{\kappa} \mathrm{B} \alpha$ levels in both neurons and astrocytes. To the contrary, anisomycin used at a subinhibitory concentration did not substantially affect $I_{\kappa} \mathrm{B} \alpha$ levels, as expected, in neurons. Therefore, it appeared that the enhanced NF- $\kappa \mathrm{B}$ binding in neurons by prolonged treatment with translational inhibitors could be attributed to a slow decay of $I_{\kappa} \mathrm{B} \alpha$ in the absence of de novo synthesis, rather than rapid targeted degradation of $\mathrm{I}_{\kappa} \mathrm{B} \alpha$.

\section{Altered NF-кB Binding Activity Is Transcriptionally Functional}

To examine a functional correlate of differential NF- $\kappa$ B activation in astrocytes and neurons in response to cytokines and microbial products, we analyzed the expression of an NF- $\kappa \mathrm{B}$-responsive gene in these cells. We had already obtained evidence that autoregulation of the NF- $\kappa \mathrm{B}$-responsive $\mathrm{I}_{\kappa} \mathrm{B} \alpha$ gene was present in astrocytes but lacking in neurons, an indication that NF- $\kappa \mathrm{B}$ was not substantially activated in neurons (Fig. 6A). Additionally, it was of particular interest to analyze the expression of the NF- $\kappa \mathrm{B}-$ responsive IRF-1 gene (Nozawa et al, 1999; Tamura et al, 1995, 1997; Tanaka et al, 1994, 1996) because of its relevance in CNS disease states (Fujimura et al, 1997; Tada et al, 1997). Neurons lacked IRF-1 gene expression following treatment with TNF- $\alpha, \mathrm{IL}-1 \beta$, LPS, and poly dl:dC (Fig. 7). To the contrary, levels of IRF-1 mRNA were much higher in astrocytes than in neurons following treatment. Interestingly, cycloheximide induced expression of the IRF-1 gene to over 109- and 40-fold in astrocytes and neurons, respectively, in agreement with the effect of cycloheximide on NF- $\kappa \mathrm{B}$ activation in both of these CNS cell types.

We next analyzed the relative binding activity of the IFN- $\gamma$-activated factor (GAF) at a gamma-activation site (GAS) adjacent to the $\kappa \mathrm{B}$ site in the IRF-1 gene

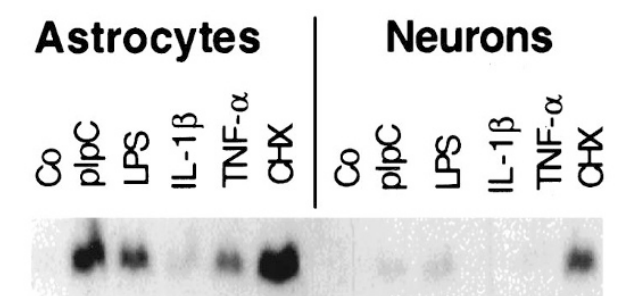

IRF-1
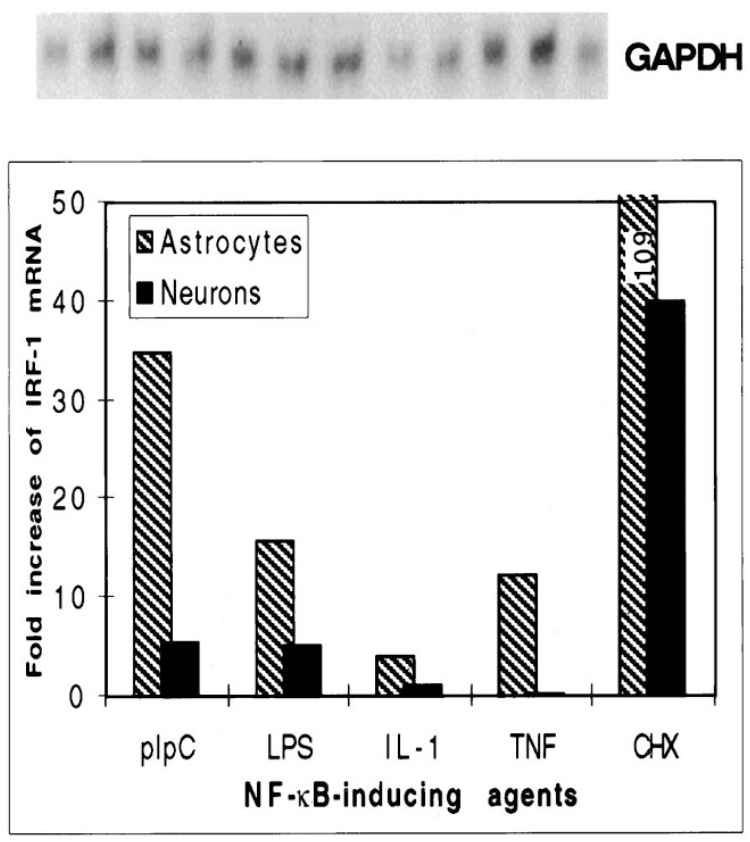

Figure 7.

Induction of IRF-1 gene transcripts following treatment with NF- $\kappa \mathrm{B}$ inducers. A, Northern blot analysis of IRF-1 mRNA expression in astrocytes and neurons treated with medium alone (Co), plpC, LPS, IL-1 $\beta$, TNF- $\alpha$, or CHX for 6 hours. The histogram represents the increase (quantity with inducer divided by quantity with medium alone) in IRF-1 mRNA after total RNA levels were corrected for using glyceraldehyde-3-phosphate dehydrogenase (GAPDH) mRNA levels. 
promoter. This was done both to determine whether a distinct cytokine signaling pathway was equally functional in neurons and astrocytes and to determine whether increased NF- $\kappa \mathrm{B}$ in conjunction with GAF could provide for synergistic transactivation of IRF-1 gene (Barber et al, 1995; Imanishi et al, 2000; Ohmori et al, 1997) in neurons. To do this, astrocytes and neurons were treated with a combination of cycloheximide and IFN- $\gamma$. In response to IFN- $\gamma$ alone, inducible GAF binding activity to the IRF-1-GAS was approximately the same in astrocytes and neurons, indicating that, unlike the NF- $\kappa$ B pathway, the Janus kinasesignal transducer and activator of transcription-1 (JAK-STAT1) pathway was fully functional in neurons relative to astrocytes (Fig. $8 A$ ). Increased GAF corresponded with increased expression of IRF-1 in both astrocytes and neurons (Fig. 8B). Importantly, the expression of IRF-1 in both neurons and astrocytes was greatly increased in response to the combined treatment with IFN- $\gamma$ and cycloheximide (Fig. 8B). The synergistic increase in IRF-1 mRNA expression in neurons was also seen in response to other protein synthesis inhibitors used in conjunction with IFN- $\gamma$ (Fig. 8C). Therefore, the efficiency of IRF-1 induction in neurons and astrocytes correlated well with the levels of NF- $\kappa \mathrm{B}$ synergy with GAF in these cells.

Because cycloheximide is able to stabilize specific mRNA species in cells through effects at the $3^{\prime}$ untranslated terminal region (3'UTR) (Edwards and Mahadevan, 1992; Wilson and Treisman, 1988), this could potentially contribute to the large increase in IRF-1 gene transcripts in neurons treated with IFN- $\gamma$ plus cycloheximide. To determine directly whether cycloheximide was stabilizing IRF-1 mRNA induced by IFN- $\gamma$, we analyzed IRF-1 mRNA degradation rates in neurons after induction with combined IFN- $\gamma /$ cycloheximide treatment in the presence of transcriptional inhibitor actinomycin D (Fig. 9). Under these conditions, cycloheximide did not affect IRF-1 mRNA decay following induction by IFN- $\gamma$ in neurons. We concluded that levels of $\mathrm{NF}-\kappa \mathrm{B}$ in neurons directly relate to increased activity of $\mathrm{NF}-\kappa \mathrm{B}$ at the $\kappa \mathrm{B}$-responsive element in the IRF-1 gene.

\section{Discussion}

In most cells exposed to NF- $\kappa \mathrm{B}$ inducing agents, including cytokines TNF- $\alpha$ and IL-1 $\beta$ and microbial products LPS and dsRNA, NF $-\kappa \mathrm{B}$ is rapidly activated to bind to $\kappa \mathrm{B}$ sites within specific gene promoters to activate transcription and appropriately respond to infections. NF- $\kappa \mathrm{B}$ is held in the cytoplasm by $\mathrm{I}_{\kappa} \mathrm{B} \alpha$ until the proper signals induce the phosphorylation and degradation of $\mathrm{I}_{\kappa} \mathrm{B} \alpha$ (Beg and Baldwin, 1993). We have described here that, in neurons, there is relatively little rapid induction of $\mathrm{NF}-\kappa \mathrm{B}$ nuclear translocation and binding following treatment with prototypic NF- $\kappa \mathrm{B}$ inducers (Figs. 2 and 4) compared with astrocytes (Figs. 3 and 4). However, latent NF $-\kappa \mathrm{B}$ is constitutively expressed in neurons, and the reduction of de novo $I_{\kappa} \mathrm{B} \alpha$ protein synthesis with translational inhibitors for prolonged periods allows NF- $\mathrm{B}$ translocation, DNA
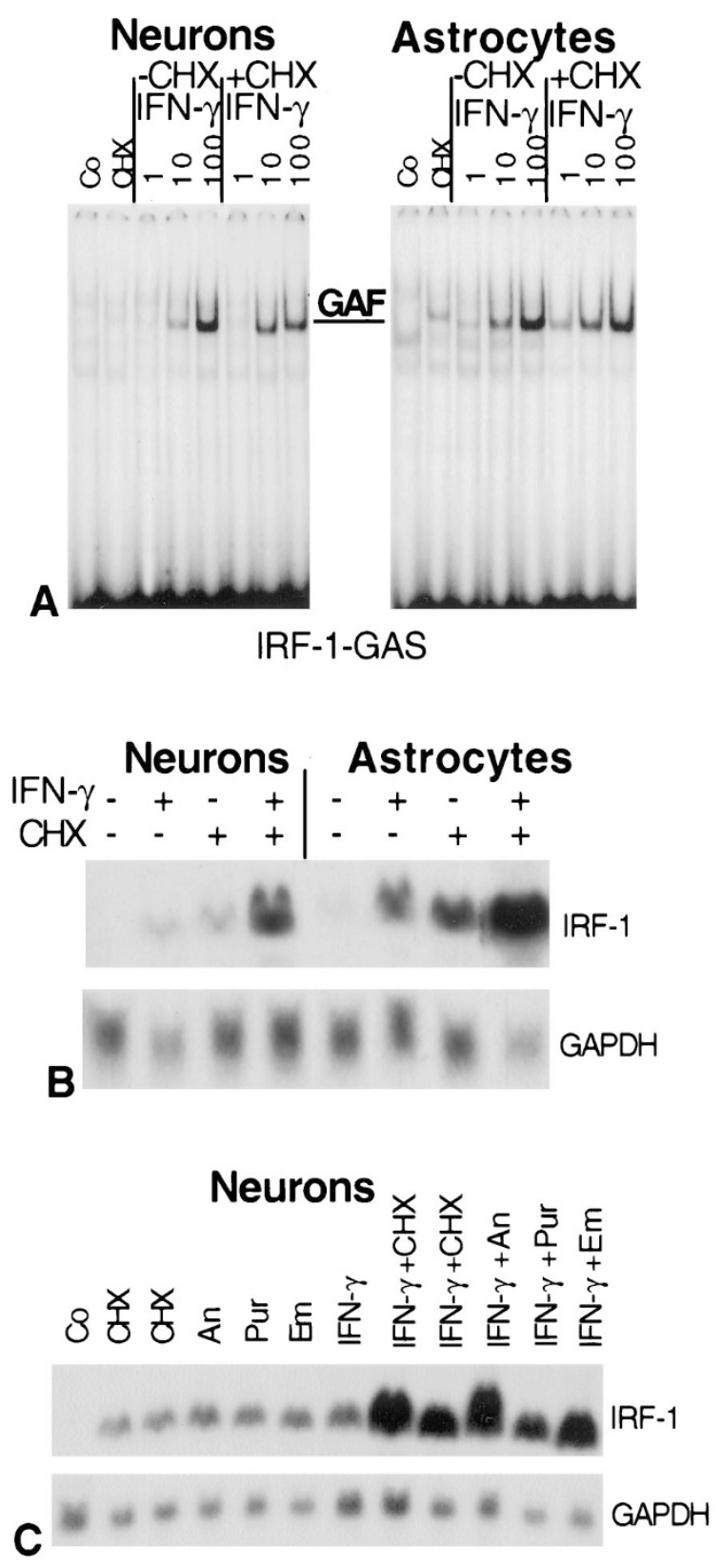

Figure 8.

A. Astrocyte and neuron cultures were treated with $(+)$ or without $(-) \mathrm{CHX}$,

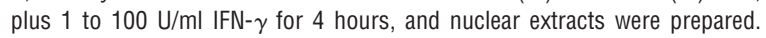
Nuclear proteins were used with the ${ }^{32}$ P-labeled duplex oligonucleotide IRF-1-GAS in an EMSA. B, The synergistic effect of cycloheximide and IFN- $\gamma$ on IRF-1 mRNA expression. Northern blot analysis of astrocyte and neuron cultures treated with media alone, IFN- $\gamma$, CHX, or IFN- $\gamma+\mathrm{CHX}$ for 6 hours. C, Synergistic IRF-1 gene induction by IFN- $\gamma$ and multiple protein synthesis inhibitors. Northern blot of neuron cultures treated with medium alone $(\mathrm{Co})$, $\mathrm{CHX}$ (two separate lots), An, Pur, or Em alone, and in combination with 100 $\mathrm{U} / \mathrm{ml}$ IFN- $\gamma$ for 6 hours.

binding, and induction of the NF- $\kappa \mathrm{B}-$ responsive IRF-1 gene. This indicated that rapid NF- $\kappa$ B activation may be generally lacking in neurons in response to the agents tested and may result from a lack of signaling pathways that otherwise promote $I_{\kappa} \mathrm{B} \alpha$ targeting/degradation.

Therefore, we analyzed inducible $\mathrm{I}_{\kappa} \mathrm{B} \alpha$ degradation following treatment with TNF- $\alpha$, a well-known inducer 

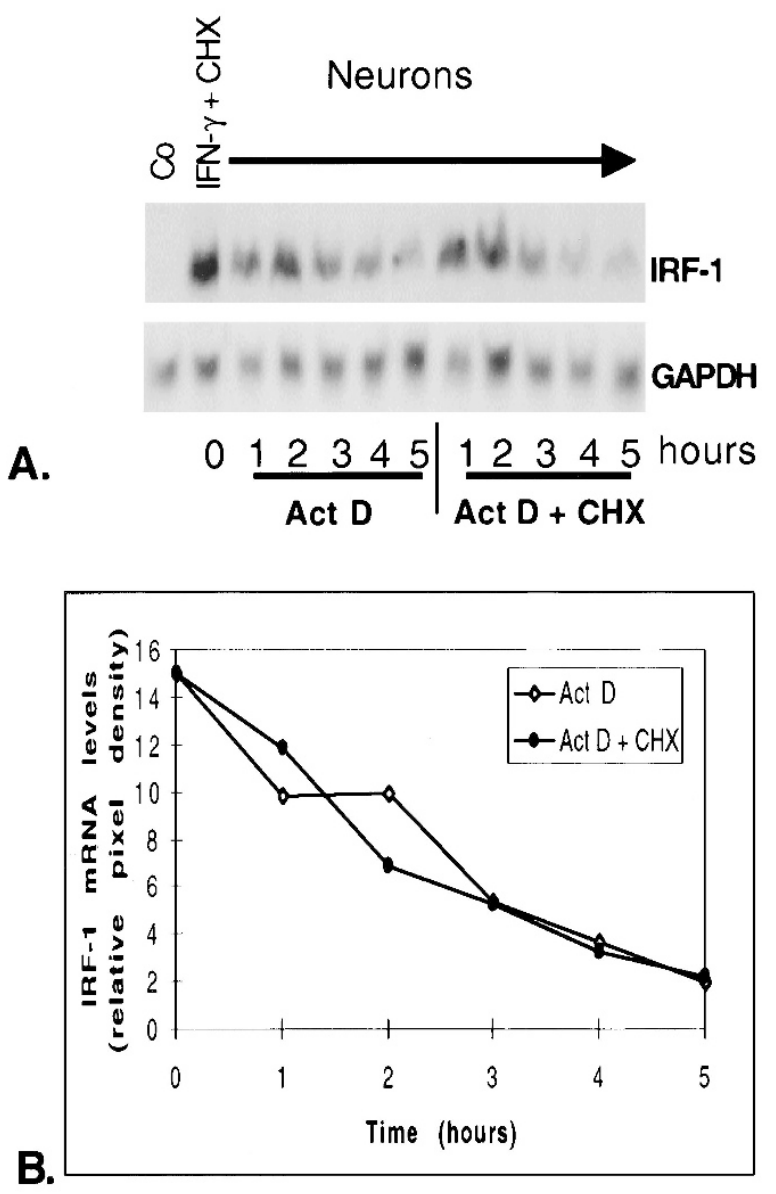

Figure 9.

Cycloheximide does not stabilize IRF-1 mRNA. A, Northern blot analysis of IRF-1 mRNA in neuron cultures treated with media alone (Co) or with IFN- $\gamma+$ $\mathrm{CHX}$ to induce IRF-1 gene transcripts. After 6 hours, the treatment media was taken off and gene transcription was blocked by adding either actinomycin $D$ (Act D) or Act D + CHX. At 0, 1, 2, 3, 4, and 5 hours later, IRF-1 mRNA levels were analyzed. B, Line graph of IRF-1 mRNA levels after the addition of Act D or Act D + CHX. IRF-1 mRNA levels were quantified and corrected for total RNA loaded relative to GAPDH.

of $I_{\kappa} \mathrm{B} \alpha$ degradation and NF- $\kappa \mathrm{B}$ activation. In astrocytes treated with TNF- $\alpha, I_{\kappa} \mathrm{B} \alpha$ levels were almost completely depleted after 15 minutes of treatment, but rebounded to normal levels within 60 minutes (Fig. 6A) via autoregulation by NF- $\kappa$ B (Sun et al, 1993). Interestingly, neurons displayed neither $I_{\kappa} \mathrm{B} \alpha$ degradation nor positive autoregulation following TNF- $\alpha$ treatment. In addition, $I_{\kappa} \mathrm{B} \alpha$ was not inducibly degraded in neurons exposed to other NF- $\kappa$ B inducers besides TNF- $\alpha$ (Fig. 6B), consistent with a general lack of NF- $\kappa \mathrm{B}$ activation in these cells (Figs. 2 and 4). To the contrary, astrocytes treated with bacterial LPS, viral mimic poly dl:dC, IL- $1 \beta$, or TNF- $\alpha$ contained from $2 \%$ to $55 \%$ of basal levels of $I_{\kappa} \mathrm{B} \alpha$ after 1 hour of treatment (Fig. 6B). Therefore, it appeared that neurons lacked inducible degradation of $I_{\kappa} \mathrm{B} \alpha$ in response to multiple inducers.

Because cycloheximide may have multiple effects on cells, including blockade of protein synthesis, increased mRNA stability, and signal transduction through the stress-activated protein kinase pathway
(SAPK) (Cano et al, 1994; Zinck et al, 1995), we determined whether the effect of cycloheximide on $\mathrm{NF}-\kappa \mathrm{B}$ activation was cycloheximide-specific. This analysis was important because agents that induce SAPK activation invariably activate NF- $\kappa$ B through common upstream signaling molecules (Leonardi et al, 2001; Li et al, 2001b, 2001c). Indeed, I $\mathrm{B} \alpha$ was rapidly degraded and NF- $\kappa \mathrm{B}$ was activated in astrocytes after short-term exposure to either anisomycin or cycloheximide, indicating that ribotoxic stress may signal to NF- $\kappa$ B in astrocytes but not in neurons (Figs. $5 \mathrm{~A}$ and $6 \mathrm{~B})$. Therefore, we analyzed NF- $\kappa \mathrm{B}$ activation and IRF-1 mRNA after longer-term treatment of neurons with four different protein synthesis inhibitors, two of which neither stabilize mRNA nor induce SAPK activation through ribotoxic stress (puromycin and emetine) (Edwards and Mahadevan, 1992). All of these inhibitors increased IRF-1 gene transcripts in neurons and acted synergistically with IFN- $\gamma$ (Fig. 8C). In addition, NF- $\kappa \mathrm{B}$ binding was enhanced in neurons by these inhibitors (Fig. 5B). Also, cycloheximide did not stabilize IRF-1 mRNA. Therefore, we conclude that the increase in IRF-1 gene transcripts in neurons in response to translational inhibitors is predominantly caused by enhanced transcriptional activity of NF- $\kappa \mathrm{B}$ in neurons in which de novo ${ }_{\kappa} \mathrm{B} \alpha$ synthesis is inhibited. In contrast, astrocytes rapidly respond to multiple stimuli, including some protein synthesis inhibitors, to degrade $I_{\kappa} \mathrm{B} \alpha$ and allow NF- $\kappa \mathrm{B}$ translocation. Recent evidence indicates that cycloheximide and anisomycin efficiently activate the SAPK pathway in astrocytes but not in neurons (PT Massa, unpublished data). Therefore, further work is underway to determine whether there is a specific molecular alteration, either at or upstream of the bifurcation point of the NF- $\kappa$ B and SAPK pathways (Leonardi et al, 2001; Li et al, 2001b, 2001c) in neurons.

$\mathrm{NF}-\kappa \mathrm{B}$ is a multifunctional transcription factor responsible for the induction of various proinflammatory, antiapoptotic, and proapoptotic genes in a cellspecific manner (Baeuerle and Baltimore, 1996), and its inducible expression by multiple stimuli is regulated through rapid cytokine-induced $\mathrm{I}_{\kappa} \mathrm{B} \alpha$ degradation (Karin, 1998; Wang et al, 1996). Our observation that neurons lack significant inducible NF- $\kappa$ B may be important in maintaining an immunoprivileged status in neurons during a viral infections, including suppression of MHC class I molecules on the cell surface of neurons (Dhib-Jalbut et al, 1999; Drew et al, 1993; Massa et al, 1993; Massa and Wu, 1995; Rall et al, 1995). Indeed, we have found that the expression of IRF-1 is critical for the transcription of MHC class I genes in neural cells (Massa and Wu, 1995), and therefore lack of NF- $\kappa \mathrm{B}$ may contribute to the silence of both IRF-1, as described here, and MHC class I genes in neurons. Therefore, the lack of NF- $\kappa$ B activation in neurons may represent a specialized adaptation to provide an immunoprivileged status in the CNS. Moreover, the efficient responses of glia to these same signals agrees well with the positive upregulation of multiple proinflammatory genes, including $\mathrm{MHC}$ class I genes that are responsive to NF- $\kappa \mathrm{B}$ 
transcriptional activity in these cells. Future studies will be focused on identifying specific components in the $I_{\kappa} \mathrm{B} \alpha$ degradation pathway that are uniquely regulated in neurons and glia and how these unique pathways of $\mathrm{NF}-\kappa \mathrm{B}$ activation might relate to specific neuronal function.

The role of $\mathrm{NF}-\kappa \mathrm{B}$ in controlling apoptosis during either development and pathological states in the CNS, particularly in neurons, has become the subject of intense research because dysregulation of this response is often associated with devastating clinical disease (Mattson et al, 2001). Despite considerable documentation of NF- $\kappa \mathrm{B}$ expression and function in controlling neuronal apoptosis, there is considerable controversy about whether NF- $\kappa \mathrm{B}$ either promotes or protects against apoptosis (Grilli and Memo, 1999a, 1999b; Kaltschmidt et al, 1999; Lezoualc'h and Behl, 1998; Mattson et al, 2001). Consistent with a possible role in neuronal survival, $\mathrm{NF}-\kappa \mathrm{B}$ has been shown to increase the expression of multiple antiapoptotic genes in various cell types, including neurons (Chen et al, 2001; Tamatani et al, 1999, 2001). However, in cells where NF- $\kappa \mathrm{B}$ promotes apoptosis, including in some neuronal systems, its activity is important for increased expression of proapoptotic molecules (Barkett and Gilmore, 1999; Cheema et al, 1999; Cruise et al, 2001; Grilli and Memo, 1999b; Grimm et al, 1996; Harwood et al, 2001; Kuhnel et al, 2001; Lee et al, 2001; Lezoualc'h and Behl, 1998; Rivera-Walsh et al, 2001; Won et al, 1999). It will undoubtedly require considerable investigation to determine the conditions, signals, and neuronal cell populations in which $\mathrm{NF}-\kappa \mathrm{B}$ expression and function is important in promoting or inhibiting apoptosis. The present investigation has attempted to determine specific signals important for expression of NF- $\kappa \mathrm{B}$ and responsive genes in the two major cell types of the CNS that are relevant for both inflammatory and neurodegenerative diseases of the CNS. The fact that latent $N F-\kappa B$ is expressed at relatively similar levels in neurons and glia suggests that NF- $\kappa \mathrm{B}$ is potentially important for responding to the unique signals required for functional responses in neurons. However these specific signaling pathways are likely to be distinct from those activated by proinflammatory cytokines or microbial products that stimulate the nuclear translocation and binding activity of $\mathrm{NF}-\kappa \mathrm{B}$ in many other cell types besides neurons.

\section{Materials and Methods}

\section{Mice}

Early-term pregnant Swiss mice were obtained from the National Cancer Institute breeding facility, Frederick, Maryland.

\section{Astrocyte and Neuronal Cultures}

Astrocytes were prepared from cerebral hemispheres of newborn mice as previously described (Massa et al, 1992, 1993). Briefly, meninges were removed from the dissected hemispheres, and the hemispheres were minced, triturated, and plated onto tissue culture plates. The astrocyte cultures were fed 5 days postplating and treated with inducing agents at 7 days. Neurons were derived from the cerebella or cerebral hemispheres of 7- to 8-day-old mice as previously described (Massa et al, 1993; Meier and Schousboe, 1982). Briefly, cerebella and cerebral hemispheres were dissected, minced, trypsinized, triturated, and then plated on tissue cultures dishes coated with poly-d-lysine. Neurons were then treated with NF- $\kappa \mathrm{B}$ inducing agents at 1 day after plating. Neurons and astrocytes from cerebral hemispheres were treated with cycloheximide, TNF- $\alpha$, or LPS at 4 days after plating and fixed and stained at 1 and 4 hours after treatment.

\section{Inducing Agents and Inhibitors}

Inducing agents were used at the following concentrations unless stated otherwise: $100 \mu \mathrm{g} / \mathrm{ml}$ dsRNA poly(I)/poly(C) (Pharmacia, Piscataway, New Jersey), 50 ng/ml LPS (Sigma Chemical Company, St. Louis, Missouri), $10 \mathrm{ng} / \mathrm{ml}$ interleukin-1 (Pharmingen, San Diego, California), 1000 Units/ml TNF- $\alpha$ (Genentech, South San Francisco, California), and $100 \mathrm{U} / \mathrm{ml}$ recombinant murine IFN- $\gamma$ (R \& D Systems, Minneapolis, Minnesota). Protein synthesis inhibitors and actinomycin D were obtained from Aldrich Chemical Company, Inc. (Allentown, Pennsylvania) and used at the following concentrations unless stated otherwise: $50 \mu \mathrm{g} / \mathrm{ml}$ cycloheximide, $10 \mathrm{~g} / \mathrm{ml}$ anisomycin, $50 \mu \mathrm{g} / \mathrm{ml}$ puromycin dihydrochloride, $10 \mu \mathrm{g} / \mathrm{ml}$ emetine dihydrochloride hydrate, and $10 \mu \mathrm{g} / \mathrm{ml}$ actinomycin D.

\section{EMSA and Oligonucleotide Probes}

Nuclear extracts from astrocytes and neurons were prepared using a mini-prep technique, as described previously (Massa et al, 1992; Nelson et al, 1993). Protein concentrations were determined using the Biorad protein assay kit (Biorad Laboratories, Richmond, California). The IRF-1- $\kappa \mathrm{B}$ and -GAS and MHCRARE duplex oligonucleotides were previously described (Massa and Wu, 1995) and synthesized by Bio-Synthesis, Inc. (Lewisville, Texas):

IRF-1- $\kappa$ B: 5' TGGGGAATCCCGC 3'

IRF-1-GAS: 5' CCTGATTTCCCCGAAATGATG 3' MHC-RARE: 5' GGTGAGGTCAGGGGTGGGG 3'

Binding of nuclear proteins to duplex oligonucleotide probes was analyzed using EMSA (Fried and Crothers, 1981; Garner and Rezvin, 1981; Massa et al, 1993). DNA probes were end-labeled with $\left[\gamma^{-32} \mathrm{P}\right]$ ATP using T4 polynucleotide kinase (Boehringer Mannheim Biochemicals, Indianapolis, Indiana). The probes (30,000 cpm/ng DNA/reaction) were incubated with 15 $\mu \mathrm{g}$ nuclear extract in the presence of $0.5 \mu \mathrm{g}$ poly $\mathrm{dl}: \mathrm{dC}$ (Pharmacia, Inc., Piscataway, New Jersey) for 30 minutes. To identify binding proteins, antibodies to transcription factors were added before the labeled probe and further incubated for 30 minutes. The reaction mixtures were electrophoresed through a $4 \%$ polyacrylamide gel, and then autoradiographed. Anti- 
bodies to NF- $\kappa$ B subunits p50 (NF- $\kappa$ B1) and p65 (Rel A) were obtained from Santa Cruz Biotechnology, Inc. (Santa Cruz, California) and used at $2 \mu \mathrm{g} \mathrm{lgG/reaction.}$

\section{Northern Blot Analysis}

Total RNA was extracted from astrocyte or neuron cultures using a guanidine isothiocyanate technique (Chomczynski and Sacci, 1987). Fifteen micrograms of RNA from each specimen was electrophoresed through a $0.9 \%$ agarose gel and then transferred to a nylon filter (Micron Separations, Inc., Westborough, Massachusetts). The RNA was hybridized with a ${ }^{32} \mathrm{P}$ labeled cDNA probe encoding murine IRF-1 generated from IRF-1 using PCR primers (forward primer, 5' AAGCCACCATGCCAATCACTCG3'; reverse primer, 5' CCCACAGGAGTCTAGCTTITTTTG 3'). Autoradiographs were quantified using an automated digitizing system (UN-SCAN-IT Gel; Silk Scientific Corporation, Orem, Utah).

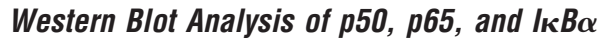

Whole cell extracts were prepared as previously described (Massa et al, 1992; Nelson et al, 1993). Briefly, cells were lysed in $50 \mu \mathrm{m}$ Tris-HCL (pH 7.4), 1\% $\mathrm{NP}-40,0.25 \%$ sodium deoxycholate, $150 \mu \mathrm{M} \mathrm{NaCl}, 1$ $\mu \mathrm{M}$ ethylene-bis(oxyethylenenitrilo)-tetraacetic acid (EGTA), $1 \mu \mathrm{M}$ phenylmethylsulfonyl fluoride (PMSF), 1 $\mu \mathrm{g} / \mathrm{ml}$ aprotinin, pepstatin, and leupeptin, $1 \mu \mathrm{M}$ activated $\mathrm{Na}_{3} \mathrm{VO}_{4}$, and $1 \mu \mathrm{M} \mathrm{NaF}$. One-hundred micrograms of protein per lane were electrophoresed through a $12.5 \%$ SDS-polyacrylamide resolving gel and electroblotted to a polyvinylidene difluoride (PVDF) membrane (Millipore Corporation, Burlington, Massachusetts). Membranes were blocked using 3\% nonfat dry milk dissolved in PBS for 30 minutes and incubated overnight with $1 \mu \mathrm{g} / \mathrm{ml}$ primary antibody diluted in $3 \%$ milk/PBS. Primary antibodies used were anti-p65 (RelA), anti-p50 (NF- $\kappa \mathrm{B} 1$ ), and anti- $\mathrm{I}_{\kappa} \mathrm{B} \alpha$ (Santa Cruz Biotechnology). Membranes were rinsed with $0.1 \%$ tween-20/PBS and incubated with horseradish peroxidase conjugated swine anti-rabbit IgG antibody (DAKO Corporation, Carpinteria, California) for 5 hours. Enhanced chemiluminescence (Amersham Life Sciences, Inc., Cleveland, Ohio) was used to visualize reactive protein bands on $\mathrm{x}$-ray film.

\section{Double Immunofluorescence Microscopy}

For in vivo studies, adult C57BL/6 mice were perfused with $4 \%$ paraformaldehyde in PBS. Brains were dissected, dehydrated, embedded in paraffin, and sectioned at $5 \mu \mathrm{m}$. For in vitro studies, neuronal cultures prepared from either cerebellum or cerebrum were treated for 1 hour with either control medium (DMEM containing $10 \%$ normal horse serum), $1000 \mathrm{U} / \mathrm{ml}$ TNF- $\alpha, 1 \mu \mathrm{g} / \mathrm{ml}$ LPS, or $50 \mu \mathrm{g} / \mathrm{ml}$ cycloheximide. The cells were fixed with $0.75 \%$ paraformaldehyde-lysineperiodate fixative in PBS for 20 minutes at room temperature. The cells were rinsed and permeabilized with $0.25 \%$ Triton-X-100 for 20 minutes. The cells and deparaffinized tissue sections were incubated over- night with a rabbit antiserum to mouse RelA $(1 \mu \mathrm{g} / \mathrm{ml}$ $\mathrm{lgG} / \mathrm{ml}$, 06-418; UBI, Lake Placid, New York) in PBS with $10 \%$ normal horse serum. After rinsing, goat anti-rabbit-TRITC (Zymed, Inc., South San Francisco, California) was placed on the cells/sections. For double staining of neuron-specific neurofilament protein or glial-specific glial fibrillary acidic protein (GFAP), the cells were further incubated with a mouse monoclonal antibody to NF 160/200kD (NF-M+H) (Clone No. RmdO-20, Zymed) or rat monoclonal antibody to GFAP (Zymed). After incubation in goat anti-mouse or anti-rat IgG-FITC, the cells were photographed by epifluorescence microscopy.

\section{References}

Arenzana-Seisdedos F, Turpin P, Rodriguez M, Thomas D, Hay RT, and Dargemont C (1997). Nuclear localization of I-Kappa-B-Alpha promotes active transport of NF-Kappa-B from the nucleus to the cytoplasm. J Cell Sci 110:369-378.

Baeuerle PA (1991). The inducible transcription activator $\mathrm{NF}-\kappa \mathrm{B}$ : Regulation by distinct protein subunits. Biochim Biophys Acta 1072:63-80.

Baeuerle PA and Baltimore D (1996). NF-Kappa-B: Ten years after. Cell 87:13-20.

Baldwin AS Jr (1996). The NF-kappa B and I kappa B proteins: New discoveries and insights. Annu Rev Immunol 14:649-683.

Barber SA, Fultz MJ, Salkowski CA, and Vogel SN (1995). Differential expression of interferon regulatory factor 1 (IRF1), IRF-2, and interferon consensus sequence binding protein genes in lipopolysaccharide (LPS)-responsive and LPShyporesponsive macrophages. Infect Immun 63:601-608.

Barkett M and Gilmore TD (1999). Control of apoptosis by Rel/NF-kappaB transcription factors. Oncogene 18:69106924.

Beg AA and Baldwin AS Jr (1993). The IkB proteins: Multifunctional regulators of Rel/NF- $\kappa$ B transcription factors. Genes Dev 7:2064-2070.

Beg AA and Baltimore D (1996). An essential role for NFkappa-B in preventing tnf-alpha-induced cell death. Science 274:782-784.

Bournat JC, Brown AM, and Soler AP (2001). Wnt-1 dependent activation of the survival factor NF-kappa B in PC12 cells. J Neurosci Res 61:21-32.

Burke PA, Hirschfeld S, Shirayoshi Y, Kasik JW, Hamada K, Appella E, and Ozato K (1989). Developmental and tissuespecific expression of nuclear proteins that bind the regulatory element of the major histocompatibility complex class I gene. J Exp Med 169:1309-1321.

Cano E, Hazzalin CA, and Mahadevan LC (1994). Anisomycin-activated protein kinases p45 and p55 but not mitogen-activated protein kinases ERK-1 and -2 are implicated in the induction of c-fos and c-jun. Mol Cell Biol 14:7352-7362.

Cheema ZF, Wade SB, Sata M, Walsh K, Sohrabji F, and Miranda RC (1999). Fas/Apo [apoptosis]-1 and associated proteins in the differentiating cerebral cortex: Induction of caspase-dependent cell death and activation of NF-kappaB. J Neurosci 19:1754-1770. 
Chen C, Edelstein LC, and Gelinas C (2001). The Rel/NFkappaB family directly activates expression of the apoptosis inhibitor Bcl-x(L). Mol Cell Biol 20:2687-2695.

Chomczynski P and Sacci N (1987). Single-step method of RNA isolation by acid guanidinium thiocyanate-phenolchloroform extraction. Anal Biochem 162:156-159.

Cruise L, Ho LK, Veitch K, Fuller G, and Morris BJ (2001). Kainate receptors activate NF-kappaB via MAP kinase in striatal neurones. Neuroreport 11:395-398.

Devergne O, McFarland EC, Mosialos G, Izumi KM, Ware CF, and Kieff $E$ (1998). Role of the TRAF binding site and NF-kappaB activation in Epstein-Barr virus latent membrane protein 1-induced cell gene expression. J Virol 72:79007908.

Dhib-Jalbut S, Xia J, Rangaviggula H, Fang YY, and Lee T (1999). Failure of measles virus to activate nuclear factorkappa B in neuronal cells: Implications on the immune response to viral infections in the central nervous system. J Immunol 162:4024-4029.

Didonato J, Mercurio F, Rosette C, Wuli J, Suyang H, Ghosh $S$, and KarinM (1996). Mapping of the inducible I-kappa-B phosphorylation sites that signal its ubiquitination and degradation. Mol Cell Biol 16:1295-1304.

Donald R, Ballard DW, and Hawiger J (1995). Proteolytic processing of NF-kB/lkB in human monocytes. J Biol Chem 270:9-12.

Drew PD, Lonergan M, Goldstein ME, Lampson LA, Ozato K, and McFarlin DE (1993). Regulation of MHC class I and $\beta 2$-microglobulin gene expression in human neuronal cells. J Immunol 150:3300-3310.

Drouet C, Shakhov AN, and Jongeneel CV (1991). Enhancers and transcription factors controlling the inducibility of the tumor necrosis factor-a promoter in primary macrophages. J Immunol 147:1694-1700.

Edwards DR and Mahadevan LC (1992). Protein synthesis inhibitors differentially superinduce c-fos and c-jun by three distinct mechanisms: Lack of evidence for labile repressors. EMBO J 11:2415-2422.

Faggioli L, Costanzo C, Merola M, Furia A, and Palmieri M (1997). Protein synthesis inhibitors cycloheximide and anisomycin induce interleukin-6 gene expression and activate transcription factor NF-kappaB. Biochem Biophys Res Comm 233:507-513.

Finco TS and Baldwin AS Jr (1995). Mechanistic aspects of NF-kappa $B$ regulation: The emerging role of phosphorylation and proteolysis. Immunity 3:263-272.

Fried M and Crothers DM (1981). Equilibria and kinetics of lac repressor-operator interactions by polyacrylamide gel electrophoresis. Nucleic Acids Res 9:6505-6525.

Fujimura M, Tominaga T, Kato I, Takasawa S, Kawase M, Taniguchi T, and Yoshimoto T (1997). Attenuation of nitric oxide synthase induction in IRF-1-deficient glial cells. Brain Res 759:247-250.

Garner M and Rezvin A (1981). A gel electrophoresis method for quantifying the binding of proteins to specific DNA regions: Applications to components of the $\mathrm{E}$. coli lactose operon regulatory system. Nucleic Acids Res 9:3047-3060.

Glasgow JN, Wood T, and Perez-Polo JR (2001). Identification and characterization of nuclear factor kappaB binding sites in the murine bcl-x promoter. J Neurochem 75:13771389.

Grilli M, Chiu JS, and Lenardo MJ (1993). NF-kB and Relparticipants in a multiform transcriptional regulatory system. Int Rev Cytol 143:1-62.

Grilli M and Memo M (1999a). Possible role of NF-kappaB and p53 in the glutamate-induced pro-apoptotic neuronal pathway. Cell Death Diff 6:22-27.

Grilli M and Memo M (1999b). Nuclear factor-kappaB/Rel proteins: A point of convergence of signalling pathways relevant in neuronal function and dysfunction. Biochem Pharmacol 57:1-7.

Grimm S, Bauer MKA, Baeuerle PA, and Schulzeosthoff K (1996). BCL-2 down-regulates the activity of transcription factor NF-kappa-B induced upon apoptosis. J Cell Biol 134:13-23.

Harada H, Takahashi E, Itoh S, Harada K, Hori TA, and Taniguchi $T$ (1994). Structure and regulation of the human interferon regulatory factor 1 (IRF-1) and IRF-2 genes: Implications for a gene network in the interferon system. Mol Cell Biol 14:1500-1509.

Harwood FG, Kasibhatla S, Petak I, Vernes R, Green DR, and Houghton JA (2001). Regulation of FasL by NF-kappaB and AP-1 in Fas-dependent thymineless death of human colon carcinoma cells. J Biol Chem 275:10023-10029.

Hazzalin CA, Cuenda A, Cano E, Cohen P, and Mahadevan LC (1997). Effects of the inhibition of p38/RK MAP kinase on induction of five fos and jun genes by diverse stimuli. Oncogene 15:2321-2331.

Hazzalin CA, Le Panse R, Cano E, and Mahadevan LC (1998). Anisomycin selectively desensitizes signalling components involved in stress kinase activation and fos and jun induction. Mol Cell Biol 18:1844-1854.

Hu Y, Baud V, Delhase M, Zhang P, Deerinck T, Ellisman M, Johnson R, and Karin M (1999). Abnormal morphogenesis but intact IKK activation in mice lacking the IKKalpha subunit of IkappaB kinase. Science 284:316-320.

Imanishi D, Yamamoto K, Tsushima $\mathrm{H}$, Miyazaki $\mathrm{Y}$, Kuriyama $\mathrm{K}$, and Tomonaga $\mathrm{M}$ (2000). Identification of a novel cytokine response element in the human IFN regulatory factor-1 gene promoter. J Immunol 165:3907-3916.

Kaltschmidt B, Kaltschmidt C, Hofmann TGH, Droge W, and Schmitz ML (2001). The pro- or anti-apoptotic function of NF-kappa B is determined by the nature of the apoptotic stimulus. Eur J Biochem 267:3828-3835.

Kaltschmidt B, Uherek M, Wellmann H, Volk B, and Kaltschmidt C (1999). Inhibition of NF-kappaB potentiates amyloid beta-mediated neuronal apoptosis. Proc Natl Acad Sci USA 96:9409-9414.

Kaltschmidt C, Kaltschmidt B, and Baeuerle PA (1993). Brain synapses contain inducible forms of the transcription factor NF- $\kappa$ B. Mech Dev 43:135-147.

Kaltschmidt C, Kaltschmidt B, Neumann $\mathrm{H}$, Wekerle $\mathrm{H}$, and Baeuerle PA (1994). Constitutive NF- $\kappa$ B activity in neurons. Mol Cell Biol 14:3981-3992.

Karin M (1998). The NF-kB activation pathway: Its regulation and role in inflammation and cell survival. Cancer $\mathrm{J}$ Sci Am 4:S92-S96. 
Karin M and Delhase M (2000). The I kappa B kinase (IKK) and NF-kappa B: Key elements of proinflammatory signalling. Semin Immunol 12:85-98.

Kuhnel F, Zender L, Paul Y, Tietze MK, Trautwein C, Manns M, and Kubicka S (2001). NFkappaB mediates apoptosis through transcriptional activation of Fas (CD95) in adenoviral hepatitis. J Biol Chem 275:6421-6427.

Lee FS, Hagler J, Chen ZJ, and Maniatis T (1997). Activation of the $I_{\kappa} \mathrm{B} \alpha$ kinase complex by MEKK1, a kinase of the JNK pathway. Cell 88:213-222.

Lee SJ, Zhou T, Choi C, Wang Z, and Benveniste EN (2001). Differential regulation and function of Fas expression on glial cells. J Immunol 164:1277-1285.

Lenardo MJ and Baltimore D (1989). NF-kappa B: A pleiotropic mediator of inducible and tissue-specific gene control. Cell 58:227-229.

Leonardi A, Chariot A, Claudio E, Cunningham $\mathrm{K}$, and Siebenlist U (2001). CIKS, a connection to I kappa B kinase and stress-activated protein kinase. Proc Natl Acad Sci USA 97:10494-10499.

Lezoualc'h F and Behl C (1998). Transcription factor NFkappaB: Friend or foe of neurons? Mol Psychiatry 3:15-20.

Li Q, Estepa G, Memet S, Israel A, and Verma IM (2001a). Complete lack of NF-kappaB activity in IKK1 and IKK2 double-deficient mice: Additional defect in neurulation. Genes Dev 14:1729-1733.

Li XX, Commane M, Jiang ZF, and Stark GR (2001b). IL-1induced NF kappa B and C-Jun N-terminal kinase (JNK) activation diverge at IL-1 receptor-associated kinase (IRAK). Proc Natl Acad Sci USA 98:4461-4465.

Li XX, Commane M, Nie HQ, Hua XX, Chatterjee-Kishore M, Wald D, and Haag MS (2001c). Act1, an NF-kappa B-activating protein. Proc Natl Acad Sci USA 97:1048910493.

Liberman TA and Baltimore D (1990). Activation of interleukin-6 gene expression through the NF- $\kappa$ B transcription factor. Mol Cell Biol 10:2327-2334.

Lieb K, Kaltschmidt C, Kaltschmidt B, Baeuerle PA, Berger $M$, and Bauer JF (1996). Interleukin-1 beta uses common and distinct signaling pathways for induction of the interleukin-6 and tumor necrosis factor alpha genes in the human astrocytoma cell line U373. J Neurochem 66:1496-1503.

Liu ZG, Hsu HL, Goeddel DV, and Karin M (1996). Dissection of TNF receptor 1 effector functions-JNK activation is not linked to apoptosis while NF-kappa-B activation prevents cell death. Cell 87:565-576.

Massa PT, Hirschfeld S, Levi B-Z, Quigley LA, Ozato K, and McFarlin DE (1992). Expression of major histocompatibility complex (MHC) class I genes in astrocytes correlates with the presence of nuclear factors that bind to constitutive and inducible enhancers. J Neuroimmunol 41:35-42.

Massa PT, Ozato K, and McFarlin DE (1993). Cell typespecific regulation of major histocompatibility complex $(\mathrm{MHC})$ class I gene expression in astrocytes, oligodendrocytes, and neurons. Glia 8:201-207.

Massa PT, Whitney LW, Wu C, Ropka SL, and Jarosinski KW (1999). Mechanism for selective induction of 2 '-5' oligoadenylate synthetase, antiviral state, but not $\mathrm{MHC}$ class I genes by interferon-beta in neurons. J Neurovirol 5:161-171.
Massa PT and Wu H (1995). Interferon regulatory factor element and interferon regulatory factor 1 in the induction of major histocompatibility complex class I genes in neural cells. J Interferon Cytokine Res 15:799-810.

Massa PT and Wu C (1998). Increased inducible activation of $\mathrm{NF}-\kappa \mathrm{B}$ and responsive genes in astrocytes deficient in the protein tyrosine phosphatase SHP-1. J Interferon Cytokine Res 18:499-507.

Mattson MP, Culmsee C, Yu Z, and Camandola S (2001). Roles of nuclear factor kappaB in neuronal survival and plasticity. J Neurochem 74:443-456.

Mattson MP, Goodman Y, Luo H, Fu W, and Furukawa K (1997). Activation of NF-kappaB protects hippocampal neurons against oxidative stress-induced apoptosis: evidence for induction of manganese superoxide dismutase and suppression of peroxynitrite production and protein tyrosine nitration. J Neurosci Res 49:681-697.

Meier E and Schousboe A (1982). Differences between GABA receptor binding to membranes from cerebellum during postnatal development and from cultured cerebellar granule cells. Dev Neurosci 5:546-553.

Natoli G, Costanzo A, Moretti F, Fulco M, Balsano C, and Levrero M (1997). Tumor necrosis factor (TNF) receptor 1 signaling downstream of TNF receptor-associated factor 2 nuclear factor kappa-B (NF-kappa-B)-inducing kinase requirement for activation of activating protein 1 and NFkappa-B but not of c-jun N-terminal kinase/stress-activated protein kinase. J Biol Chem 272:26079-26082.

Nazar AS, Cheng G, Shin HS, Brothers PN, Dhib-Jalbut S, and Vanguri $P$ (1997). Induction of IP-10 chemokine promoter by measles virus: Comparison with interferon-gamma shows the use of the same response element but with differential DNA-protein binding profiles. J Neuroimmunol 77:116-127.

Nelson N, Marks MS, Driggers PH, and Ozato K (1993). Interferon consensus sequence-binding protein, a member of the interferon regulatory factor family, suppresses interferoninduced gene transcription. Mol Cell Biol 13:588-599.

Newton R, Adcock IM, and Barnes PJ (1996). Superinduction of NF-kappa B by actinomycin D and cycloheximide in epithelial cells. Biochem Biophys Res Comm 218:518-523.

Nozawa H, Oda E, Nakao K, Ishihara M, Ueda S, Yokochi T, Ogasawara K, Shimizu S, Ohira Y, Hioki K, Aizawa S, Ishikawa T, KatsukiM., Muto T, Taniguchi T, and Tanaka N (1999). Loss of transcription factor IRF-1 affects tumor susceptibility in mice carrying the Ha-ras transgene or nullizygosity for p53. Genes Dev 13:1240-1245.

O'Neill LA and Kaltschmidt C (1997). NF-kappa B: A crucial transcription factor for glial and neuronal cell function. Trends Neurosci 20:252-258.

Ohmori Y, Schreiber RD, and Hamilton TA (1997). Synergy between interferon-gamma and tumor necrosis factor-alpha in transcriptional activation is mediated by cooperation between signal transducer and activator of transcription 1 and nuclear factor kappaB. J Biol Chem 272:14899-14907.

Palombella VJ, Rando OJ, Goldberg AL, and Maniatis T (1994). The ubiquitin-proteasome pathway is required for processing the NF-kappa B1 precursor protein and the activation of NF-kappa B. Cell 78:773-785.

Rall GF, Mucke L, and Oldstone MBA (1995). Consequences of cytotoxic T lymphocyte interactions with major histocom- 
patibility complex class I-expressing neurons in vivo. J Exp Med 182:1201-1212.

Rivera-Walsh I, Cvijic ME, Xiao G, and Sun SC (2001). The NF-kappa B signaling pathway is not required for Fas ligand gene induction but mediates protection from activationinduced cell death. J Biol Chem 275:25222-25230.

Schneider A, Martin-Villalba A, Weih F, Vogel J, Wirth T, and Schwaninger M (1999). NF-kappa B is activated and promotes cell death in focal cerebral ischemia. Nat Med 5:554559.

Sen R and Baltimore D (1986). Inducibility of kappa immunoglobulin enhancer-binding protein NF-kappa B by a posttranslational mechanism. Cell 47:921-928.

Song HY, Rothe M, and Goeddel DV (1996). The tumor necrosis factor-inducible zinc finger protein A20 interacts with TRAF1/TRAF2 and inhibits NF-kappa-B activation. Proc Natl Acad Sci USA 93:6721-6725.

Sparacio SM, Zhang Y, Vilcek J, and Benveniste EN (1992). Cytokine regulation of interleukin- 6 gene expression in astrocytes involves activation of an NF-kappa B-like nuclear protein. J Neuroimmunol 39:231-242.

Sun SC, Ganchi PA, Ballard DW, and Greene WC (1993). NF-kappa B controls expression of inhibitor I kappa B alpha: Evidence for an inducible autoregulatory pathway. Science 259:1912-1915.

Tada Y, Ho A, Matsuyama T, and Mak TW (1997). Reduced incidence and severity of antigen-induced autoimmune diseases in mice lacking interferon regulatory factor-1. J Exp Med 185:231-238.

Tamatani M, Che YH, Matsuzaki H, Ogawa S, Okado H, Miyake S, and Mizuno T (1999). Tumor necrosis factor induces $\mathrm{Bcl}-2$ and $\mathrm{Bcl}-\mathrm{x}$ expression through NFkappaB activation in primary hippocampal neurons. J Biol Chem 274: 8531-8538.

Tamatani M, Mitsuda N, Matsuzaki $\mathrm{H}$, Okado $\mathrm{H}$, Miyake S, Vitek MP, and Tohyama M (2001). A pathway of neuronal apoptosis induced by hypoxia/reoxygenation: Roles of nuclear factor-kappaB and Bcl-2. J Neurochem 75:683-693.

Tamura T, Ishihara M, Lamphier MS, Tanaka N, Oishi I, Aizawa S, Mak TW, Taki S, and Taniguchi T (1995). An IRF-1-dependent pathway of DNA damage-induced apoptosis in mitogen-activated T lymphocytes. Nature 376:596599.

Tamura T, Ishihara M, Lamphier MS, Tanaka N, Oishi I, Aizawa S, Mak TW, Taki S, and Taniguchi T (1997). DNA damage-induced apoptosis and Ice gene induction in mitogenically activated $\mathrm{T}$ lymphocytes require IRF-1. Leukemia 11(Suppl 3):439-440.

Tanaka N, Ishihara M, Kitagawa M, Harada H, Kimura T, Matsuyama T, Lamphier MS, Aizawa S, Mak TW, and Taniguchi T (1994). Cellular commitment to oncogene-induced transformation or apoptosis is dependent on the transcription factor IRF-1. Cell 77:829-839.

Tanaka N, Ishihara M, Lamphier MS, Nozawa H, Matsuyama T, Mak TW, Aizawa S, Tokino T, Oren M, and Taniguchi T (1996). Cooperation of the tumour suppressors IRF-1 and p53 in response to DNA damage. Nature 382:816-818.
Ten RM, Blank V, Le Bail O, Kourilsky P, and Israel A (1993). Two factors, IRF1 and KBF1/NF-kappa B, cooperate during induction of $\mathrm{MHC}$ class I gene expression by interferon alpha beta or Newcastle disease virus. C R Acad Sci III 316:496501.

Traenckner EB-M, Pahl HL, Henkel T, Schmidt KN, Wilk S, and Baeuerle PA (1995). Phosphorylation of human $I_{\kappa} B-\alpha$ on serines 32 and 36 controls $I_{\kappa} \mathrm{B}-\alpha$ proteolysis and NF-kB activation in response to diverse stimuli. EMBO J 14:2876-2883.

Wang CY, Mayo MW, and Baldwin AS Jr (1996). TNF- and cancer therapy-induced apoptosis: Potentiation by inhibition of NF-kappaB. Science 274:784-787.

Wang CY, Mayo MW, Korneluk RG, Goeddel DV, and Baldwin AS Jr (1998). NF-kappaB antiapoptosis: Induction of TRAF1 and TRAF2 and C-IAP1 and C-IAP2 to suppress caspase-8 activation. Science 281:1680-1683.

Ward LA and Massa PT (1995). Neuron-specific regulation of major histocompatibility complex class I, interferon- $\beta$, and anti-viral state genes. J Neuroimmunol 58:145-155.

Wilson $T$ and Treisman R (1988). Removal of poly(A) and consequent degradation of c-fos mRNA facilitated by $3^{\prime} \mathrm{AU}$ rich sequences. Nature 336:396-398.

Won SJ, Ko HW, Kim EY, Park EC, Huh K, Jung NP, Choi I, Oh YK, Shin HC, and Gwag BJ (1999). Nuclear factor kappa B-mediated kainate neurotoxicity in the rat and hamster hippocampus. Neuroscience 94:83-91.

Woronicz JD, Gao X, Cao Z, Rothe M, and Goeddel DV (1997). IkappaB kinase-beta: NF-kappaB activation and complex formation with IkappaB kinase-alpha and NIK. Science 278:866-869.

Xie Q, Whisnant R, and Nathan C (1993). Promoter of the mouse gene encoding calcium-independent nitric oxide synthase confers inducibility by interferon $\gamma$ and bacterial lipopolysaccharide. J Exp Med 177:1779-1784.

Zamanian-Daryoush M, Mogensen TH, DiDonato JA, and Williams BRG (2000). NF-kappa B activation by doublestranded-RNA-activated protein kinase (PKR) is mediated through NF-kappa B-inducing kinase and I kappa B kinase. Mol Cell Biol 20:1278-1290.

Zandi E, Rothwarf DM, Delhase M, Hayakawa M, and Karin M (1997). The IkappaB kinase complex (IKK) contains two kinase subunits, IKKalpha and IKKbeta, necessary for IkappaB phosphorylation and NF-kappaB activation. Cell 91: 243-252.

Zinck R, Cahill MA, Kracht M, Sachsenmaier C, Hipskind RA, and Nordheim A (1995). Protein synthesis inhibitors reveal differential regulation of mitogen-activated protein kinase and stress-activated protein kinase pathways that converge on Elk-1. Mol Cell Biol 15:4930-4938. 